\title{
DISCUSSION
}

\section{PUBLICATION ACTIVITY OF NEW SLOVAK PROFESSORS IN ECONOMICS AND ITS INTERNATIONAL RECEPTION}

\author{
Juraj Barta, Michal Považan*
}

\begin{abstract}
:
The paper deals with quality of economic research in Slovakia, which is strongly connected with quality of economic education at Slovak universities. Quality of economic research is described by publication activity of Slovak professors of economics, who are usually the leaders in number of publications and citations and used to be internationally recognised.

The paper does not seek for possible roots or explanations of the situation. It only tries to describe the status quo and provide useful data and comparisons.
\end{abstract}

Keywords: quality, economic, professor, Slovak, research, education, scientometrics

JEL Classification: 123, A11

\section{Preliminary Remarks}

Economic education in Slovakia has been a topic of discussion and (mostly) criticism for at least ten years. Even Fidrmuc (1998) concludes that the level of economic education in Slovakia is rather poor. After his study, many other opinions of students, graduates, and economic practitioners were similarly critical to institutions providing higher education in economics in Slovakia. Public view of these institutions can be described by the fact, that none of the economists from Slovak universities has ever been listed among the most quoted economic experts (Š́́poš, 2009), the ranking occupied by economists from non-governmental institutions, Slovak Academy of Sciences, central bank or even commercial banks.

We strongly believe that good research is condition sine qua non of good education. Only those who actively take part in the global exchange of ideas can provide their students with most recent stance of economic thinking, and they also most probably

* Juraj Barta, Akademic Ranking and Rating Agency, Bárdošova 2/A, 83101 Bratislava, SK (bartaj@, chello.sk); Michal Považan, Faculty of Law, Comenius University in Bratislava, Šafárikovo nám. 6, 81000 Bratislava, SK (povazan@gmail.com). 
have the necessary knowledge and understanding of the development and history of economic science. The poor quality of research in Slovak academia, evidence of which we will give in this article, is one of the key reasons for poor quality and perception of economic education. Furthermore, it is also a key limiting factor for improving the situation in future.

The purpose of this paper is not to seek for possible roots or explanations of the situation. We only try to describe the status quo and provide useful data and comparisons.

For the data-based comparison of Slovak research in the area of economics, we will use basic scientometric criteria obtained from internationally recognised databases of World of Science (WoS) and EconLit, as well as scores such as the Hirsch index as proposed in Hirsch (2005).

We are well aware of limitations and shortcomings of scientometrics. More specifically, there are many alternative measures that are trying to improve the original Hirsch index, such as g-index, r-index or f-index using arithmetic or geometric averages of per paper citations, or their square roots (Tol, 2009). Additionally, papers and citations cannot create any concise nor complete picture of a research performance. As shown by Horvath (2008), albeit not very known outside Slovakia, there always were and still are inspiring economic thinkers there. However, we think that using scientometric measures can provide us with useful basic description of the current level of economic research, as well as it allows simple comparison to other countries in our region. Moreover, economics is a global, not regional science. Results of an individual's research can only be validated in a discourse within the community of researchers focused on the same topic, and this is only possible, if the result is published and perceived by this community. Therefore it is considered to be important to publish the research results, preferably in English, and in journals with high impact factor to make it accessible for the widest possible readership.

Of course, more sophisticated methods of performance evaluation exist or can be developed, such as data envelopment analysis using multiple of input and output parameters (e.g. Sinuany-Stern et al., 1994, for analysis of departments at Ben-Gurion University). Still, the research performance can serve as the first step in this work. As Web of Science is not univocally considered to be the best source of data for economics, we use also the EconLit as an alternative data base. Unsurprisingly, as it is true for other alternatives such as Google Scholar or Scopus, correlation between rankings obtained by these sources is very high (Della Seta and Camarano, 2006).

Except one scientific article concerning quality of economic research in Slovak universities (Ciaian, Pokrivčák, Rajcaniová, 2005), we could not find any comprehensive source of basic scientometric data on Slovak economics (unlike e.g. several different sources available for the Czech ones - Turnovec, Macháček, Münich, Klocová). This article can be viewed also as a source of information of this kind.

In the first part, we will analyse the total research production (in terms of publications and citations) in Slovakia in recent decades. We will focus on general description, as well a selection of most successful papers and most influential economists. We 
will compare most of these data with those of the Czech Republic, Hungary (as our regional peers) and Austria (as a representative of countries with highly developed economic research). In the second part, we will closely analyse the research results of the most prominent academics, i.e. those who received professorship after 1993. We will conclude with overview of some possible reasons of our findings, and ways how to change the situations stemming from them. Throughout the whole article, we use data obtained via General Search from international data base WoS. Although the Cited reference search could be more complex, we opted not to choose it due to lower quality of underlying data and less comfortable usage of the searching tools. We are aware of (not only) recent criticism of the usage of WoS data in this regard, see e.g. Artlova (2010). However, due to very essence of statistical data and measurement, the distribution of potential errors among authors shall be just, and shall play more minor role for scientists with large number of both publications and citations.

\section{Slovak Economic Research}

\subsection{Publications}

In the period of 1985-2009, there were altogether 868 articles published in economics with at least one author with Slovak domicile. This obviously does not include most of the articles of authors from Slovakia who published before 1992 (split of Czechoslovakia). We can assume that Slovak authors have some $30-40 \%$ share on 1253 publications in economics witch Czechoslovak domicile. However, we do not include these in our comparisons, and the same is true for the Czech Republic. This should be remembered in making any comparison with other countries.

As it can be seen in Table 1, number of articles is roughly comparable with that of the Czech Republic and Austria, and more than double of that of Hungary (with 8 years longer periods taking into account in both Austria and Hungary). Considering the population of compared countries, Slovak researchers are more productive in terms of publications than any of their peers. Possible reasons are analysed later in this article.

Table 1

Number of Publications, Publications per One Million Inhabitants and Average Number of Publications per Year in 1985-2009 in Four Central European Countries

\begin{tabular}{|l|c|c|c|c|}
\hline \multirow{2}{*}{} & \multicolumn{4}{|c|}{ 1985-2009 } \\
\cline { 2 - 5 } & Slovakia** $^{*}$ & Hungary & Czech Republic $^{* *}$ & Austria \\
\hline Number of Publications & 868 & 345 & 998 & 1017 \\
\hline $\begin{array}{l}\text { Publications per One } \\
\text { Million Inhabitants* }\end{array}$ & 161 & 35 & 98 & 124 \\
\hline $\begin{array}{l}\text { Average Number of } \\
\text { Publications per Year }\end{array}$ & 51 & 14 & 62 & 42 \\
\hline
\end{tabular}

* Number of population is taken from CIA World Fact Book

** Due to existence of Czecho-Slovakia until 1993, all numbers in the table are for years 1993-2009. 
There is no trend visible in number of articles yearly, so it is possible to state that the economic research activity in Slovakia stagnates in between 40-70 research papers published each year. Contrariwise, there is clear upward trend in publication activity in recent 3 years in the Czech Republic and last 5 years in Hungary; and even steady growth in Austria.

\subsection{Citations}

The picture painted by citations is far less bright. Total number of citations recorded in the same period is 444 . That means, an average paper of a Slovak researcher is quoted 0.51-times. Vast majority (74\%) are not cited at all. That means, in other words, that almost three quarters of papers published by Slovak economists does not contain any finding or idea worth to be mentioned again. Or, frankly, were there not published, nobody would miss them. Apparently very similar data can be obtained for the Czech economists - out of 998 works, $72 \%$ were not quoted. However, total number of citations is 998, bringing the citations-per-paper to 1.00, twice as much as in Slovakia.

In Hungary, the situation is even more different. Relatively small number of works is outweighed by high per-paper number of citations. Still, almost one half of the articles were not cited. On the other hand, 2/3 of Austrian papers have at least one citation, with average article quoted 11 times more frequently as an average Slovak paper.

Table 2

Number of Citations, Citations per Publication, Number of at Least One Time Cited Paper, Number of Citations of the Most Cited Paper and Country h-index in Economics in 1985-2009 in Four Central European Countries

\begin{tabular}{|l|c|c|c|c|}
\hline \multirow{2}{*}{} & \multicolumn{4}{|c|}{ 1985-2009 } \\
\cline { 2 - 5 } & Slovakia* & Hungary & $\begin{array}{c}\text { Czech } \\
\text { Republic* }\end{array}$ & Austria \\
\hline Number of Citations & 444 & 1228 & 998 & 5452 \\
\hline Citations per Publication & 0.51 & 3.56 & 1.00 & 5.38 \\
\hline Number of at Least One Time Cited Paper & 228 & 180 & 276 & 682 \\
\hline Share of at Least One Time Cited Paper & $26 \%$ & $52 \%$ & $28 \%$ & $67 \%$ \\
\hline Number of Citations of the Most Cited Paper & 14 & 174 & 62 & 315 \\
\hline Country h-index in Economics & 7 & 17 & 13 & 30 \\
\hline
\end{tabular}

* Due to existence of Czecho-Slovakia until 1993, all numbers in the table are after that year.

Austrian economists publish a lot of highly recognised papers, mirrored in high h-index and in 315 citations of the most cited paper in the last 24 years. Hungarians publish much less, but are cited much more than Czechs or Slovaks. And there is an important difference between Czech and Slovak researchers as well - there is a relatively small group of authors who publish regularly and their work is influential 
within the international community in the Czech Republic, although to much lesser extent than in Hungary or Austria. But we lack even such a small group in Slovakia. For comparison, the total publication activity of Slovak economic researchers from 1993, measured by the Hirsch index of 7, is lower than that of one single University of Chicago professor with Slovak routes, Luboš Pástor (publishing since 1999, he already has a h-index of 11). That means, that all Slovak scientists together produced only 7 articles with more than 7 citations each, whereas professor Pástor wrote 11 articles with more than 11 citations each, although he actively worked only for one half of the reviewed time period.

\subsection{Journals and language of publications}

Closeness and absence of communication with the outside world becomes even more obvious after closer look at journals in which research results are published. Out of above mentioned 868 papers, $86 \%$ were issued in Ekonomický časopis, Slovak journal included in the current contents list, and monitored by the WoS data base. Furthermore, adding Czech-based economic journals to this figure, we conclude at alarming $92 \%$ of all articles published in Slovak or Czech journals. Thus, Slovak economic research can easily be described as "Ekonomický časopis circle". In the Czech Republic, the figure is 76 (including Ekonomický časopis), in Austria it is only 6\%. There is no economic journal registered in Hungary, which is most probably behind the lower productivity of non-cited works by Hungarian researchers.

Table 3

Language Used by Researchers to Publish Their Papers in 1985-2009 in Four Central European Countries

\begin{tabular}{|l|c|c|c|c|}
\hline \multirow{2}{*}{ Language of the Article } & \multicolumn{4}{|c|}{$\mathbf{1 9 8 5 - 2 0 0 9}$} \\
\cline { 2 - 5 } & Slovakia* $^{*}$ & Hungary & Czech Republic* & Austria \\
\hline Slovak & $66 \%$ & $0 \%$ & $2 \%$ & $0.6 \%$ \\
\hline Czech & $13 \%$ & $4 \%$ & $58 \%$ & $0.3 \%$ \\
\hline German & $0 \%$ & $0 \%$ & $0 \%$ & $2 \%$ \\
\hline English & $21 \%$ & $91 \%$ & $39 \%$ & $97 \%$ \\
\hline Other & $0.02 \%$ & $5 \%$ & $2 \%$ & $0.2 \%$ \\
\hline
\end{tabular}

* Due to existence of Czecho-Slovakia until 1993, all numbers in the table are after that year.

Almost $80 \%$ of papers published by Slovak scientists is in Slovak or Czech language (n.b. Slovak and Czech journals also sometimes publish articles in English). For comparison, $40 \%$ of Czech, $95 \%$ of Hungarian and $97 \%$ of Austrian papers are in English or (marginal number) French. 
Table 4

Journals where Slovak Economic Scientists Publish

\begin{tabular}{|l|c|c|}
\hline & \multicolumn{2}{|c|}{ 1993-2009 } \\
\hline $\begin{array}{l}\text { Journals Where Slovak Economic } \\
\text { Scientists Publish }\end{array}$ & $\begin{array}{c}\text { Number of Published } \\
\text { Paper }\end{array}$ & Share on Total \\
\hline Ekonomický časopis & 754 & $87 \%$ \\
\hline Politická ekonomie & 41 & $5 \%$ \\
\hline $\begin{array}{l}\text { Agricultural Economics - Zemědělská } \\
\text { ekonomika }\end{array}$ & 33 & $4 \%$ \\
\hline E \& M Ekonomie a management & 17 & $2 \%$ \\
\hline Journal of Comparative Economics & 6 & $0.7 \%$ \\
\hline Economics of Transition & 4 & $0.5 \%$ \\
\hline International Journal of Game Theory & 4 & $0.5 \%$ \\
\hline Post-communist Economies & 4 & $0.5 \%$ \\
\hline EUROPE-ASIA Studies & 3 & $0.4 \%$ \\
\hline Applied Economics & 2 & $0.2 \%$ \\
\hline
\end{tabular}

The Impact Factor (IP), a measure reflecting the average number of citations to articles published in science journals, is used to compare different journals within a certain field. The higher IP is, the more researchers read the journal and thereby the impact of the article on community of researchers is bigger.

The Web of Knowledge indexes 209 science journals from fields Economics and the results are widely (though not freely) available. Average 5 -year impact factor of first 20 journals in the field in 2003-2008 is 4,347 comparing to 0,186 in case of Ekonomický časopis.

Table 5

Time Change of 5-Year Impact Factor of Ekonomický časopis

\begin{tabular}{|l|c|c|c|c|c|}
\hline & \multicolumn{5}{|c|}{ Impact Factor } \\
\cline { 2 - 6 } & $\mathbf{1 9 9 9 - 2 0 0 4}$ & $\mathbf{2 0 0 0 - 2 0 0 5}$ & $\mathbf{2 0 0 1 - 2 0 0 6}$ & $\mathbf{2 0 0 2 - 2 0 0 7}$ & $\mathbf{2 0 0 3 - 2 0 0 8}$ \\
\hline $\begin{array}{l}\text { Ekonomický } \\
\text { časopis }\end{array}$ & 0,123 & 0,204 & 0,268 & 0,115 & 0,186 \\
\hline
\end{tabular}

Assuming that, by definition, an article in a journal with higher impact factor has higher chance to be noticed and cited, it is not surprising, that Slovak economic research has such a poor reflection in the international economic community. Publishing the results in local journals and mostly in Slovak is not a good way how to attract international attention. Of course, publishing the article in English is not enough, but it is an elementary pre-condition of successful scientific performance. Not mentioning the fact, that - unlike the very demanding selection process applied to articles published 
in renowned international journals - local papers reportedly have problems to fill their pages with articles, and therefore apply only very vague quality criteria on submitted papers.

\subsection{Prominent authors}

Interesting picture can be obtained by taking a look at most publishing authors. In Slovakia, these are listed in Table 5. For comparison, the most frequently publishing Hungarian economist is János Kornai, who, as the only representative of Central and Eastern Europe, is included in the Blaug (1985) list of 100 major economists after Keynes. He published 20 articles (Okáli has 28), however, only in international journals. Once again, it is not quantity that counts.

Table 6

Most Publishing Slovak Economic Scientists in 1993-2009

\begin{tabular}{|l|c|c|}
\hline $\begin{array}{l}\text { Most Publishing Slovak } \\
\text { Economic Scientists }\end{array}$ & $\begin{array}{c}\text { Number of Published } \\
\text { Papers }\end{array}$ & $\begin{array}{c}\text { Share of Published } \\
\text { Papers }\end{array}$ \\
\hline Okali, I. & 28 & $3.2 \%$ \\
\hline Gabrielova, H. & 25 & $2.9 \%$ \\
\hline Outrata, R. & 24 & $2.8 \%$ \\
\hline Balaz, V. & 16 & $2.2 \%$ \\
\hline Balaz, P. & 18 & $2.1 \%$ \\
\hline Morvay, K. & 18 & $2.1 \%$ \\
\hline Hlavaty, E. & 16 & $1.8 \%$ \\
\hline Brzica, D. & 14 & $1.6 \%$ \\
\hline Isa, J. & 14 & $1.6 \%$ \\
\hline Nemec, J. & 14 & $1.6 \%$ \\
\hline
\end{tabular}

For the purposes of later analysis, it is not useless to mention that out of these most publishing researchers, only 2 are professors; and, vice versa, only 2 professors introduced in recent 18 years are among the most publishing authors.

\subsection{Comparison with the world}

To support the underlying assumption of this article - that is, that economic research quality can be measured and compared using the publication and citation data, or the Hirsch index, we include the table put together by Czech economists Machacek and Kolcunova (2008) (Table 8), and table of probably most prominent Slovak economist in the Table 8 . 
Table 7

Scientometric Data of Reputable Economists

\begin{tabular}{|c|c|c|c|c|c|c|}
\hline Surname & First Name & $h$-index & $\begin{array}{c}\text { Number } \\
\text { of Cited } \\
\text { Publications }\end{array}$ & $\begin{array}{l}\text { Ratio of Cited } \\
\text { Publications } \\
\text { on Total }\end{array}$ & $\begin{array}{c}\text { Number of } \\
\text { Citations }\end{array}$ & $\begin{array}{c}\text { Number of Citations } \\
\text { of the Most Cited } \\
\text { Paper }\end{array}$ \\
\hline Stiglitz & Joseph E. & 36 & 135 & $89 \%$ & 5949 & 1078 \\
\hline Fama & Eugene F. & 34 & 54 & $96 \%$ & 8386 & 988 \\
\hline Mankiw & N. Gregory & 33 & 119 & $56 \%$ & 3885 & 775 \\
\hline Barro & Robert J. & 29 & 66 & $83 \%$ & 5676 & 1023 \\
\hline Obstfeld & Maurice & 28 & 63 & $91 \%$ & 2240 & 181 \\
\hline Krugman & Paul & 25 & 108 & $57 \%$ & 3010 & 631 \\
\hline Rogoff & Kenneth & 22 & 50 & $74 \%$ & 3089 & 528 \\
\hline Prescott & Edward C. & 20 & 49 & $84 \%$ & 2825 & 789 \\
\hline Akerlof & George A. & 19 & 38 & $90 \%$ & 2172 & 360 \\
\hline Sargent & Thomas J. & 18 & 58 & $86 \%$ & 1371 & 243 \\
\hline McCallum & Bennet T. & 18 & 58 & $85 \%$ & 1059 & 124 \\
\hline Varian & Hal R. & 19 & 48 & $79 \%$ & 1499 & 237 \\
\hline Sachs & Jeffrey & 15 & 60 & $80 \%$ & 926 & 167 \\
\hline
\end{tabular}

Table 8

Scientometric Data of Reputable Slovak Economists Working outside Slovakia

\begin{tabular}{|l|l|c|c|c|c|c|}
\hline Surname & First Name & h-index & $\begin{array}{c}\text { Number } \\
\text { of Cited } \\
\text { Publications }\end{array}$ & $\begin{array}{c}\text { Share of Cited } \\
\text { Publications on } \\
\text { Total }\end{array}$ & $\begin{array}{c}\text { Number of } \\
\text { Citations }\end{array}$ & $\begin{array}{c}\text { Number of } \\
\text { Citations of the } \\
\text { Most Cited Paper }\end{array}$ \\
\hline Pástor & L'uboš & 11 & 12 & $86 \%$ & 397 & 115 \\
\hline Fidrmuc & Jarko & 5 & 15 & $56 \%$ & 94 & 22 \\
\hline
\end{tabular}

\section{Slovak Professors of Economics}

\subsection{Reasoning}

Educational and research system in Slovakia has experienced rapid development for last 20 years. With increasing number of universities with economic faculties and number of students, amount of new professors had to be enhanced as well. Since 1993, altogether 102 new professors in economics were inaugurated, i.e. 5.7 professor every year.

To be inaugurated as a professor in Slovakia means to fulfil conditions generally stated in Higher Education Act of 2002 and in detail in other legal documents mostly approved by individual university or faculty. Professors are expected to be extraordinary 
personalities with well known research results and educational experience, their research should have international relevance. They should undergo thorough procedure within their universities, have to prove their ability in front of the scientific councils of these institutions and, after fulfilling all required criteria, are given the life-long privilege to bear the title of professor by the state president.

It is reasonable to presuppose that newly appointed professors are "the best what faculty or university has at that time", crème de la crème of the renowned academia. It is believed that this quality is easily observable in their research activity, measured by publications and citations in respected journals. As mentioned above, this is also required by law and demanded by most of prerequisites for professorship officially developed and adopted by universities (Pišút, Pišútová, 2007). Their publications and their quotations reflect fastidiousness of criteria stated by the faculty or the university to apply successfully for professorship. New appointed professors are at the pick of their academic careers and they are intellectual elite of the nation in their respective fields.

For these reasons, we focused on research activity and quality of all new professors of economics named since 1993. We know about professors who have their titles also from earlier periods, however, due to old communist regime heavy interference to all social sciences (including economics) we assume these being rather obsolete.

\subsection{Publications}

As we mentioned above, nowadays, none of the most publishing Slovak economists is full-time employee of a university in Slovakia. 102 new professors in economics appointed since 1993 published 255 articles (34\% of all published after 1985). 206 papers were published in Ekonomický časopis, a journal realising by Institute of Economics of Slovak Institute of Science and which concerns articles mostly in Slovak language. 216 out of 255 articles were published in a Slovak journal. Only 39 papers $(27 \%)$ were published in foreign journals, Czech journals are here included (29 papers). One appointed professor has published 2.5 scientific papers in respected journal for last 25 years, period comparable to more than a half of the life time career for most of them.

Out of the list of 102 professors, as much as 33 have never published any research paper. 78 of them $(76.5 \%)$ have never had an article in a foreign scientific journal (not even in one of those issued in the Czech Republic, accepting articles also in Slovak language).

Results above are from WoS. According to database EconLit, Slovak professors of economics published 138 papers, even less than according to WoS. Only 54 professors have ever published a paper indexed in EconLit, only two Slovak professors have more than 10 papers indexed in EconLit. EconLit does not cover citations, but when we generalize comparison between WoS and EconLit in number of papers, we can derive 
result for citations very easily. For even less papers indexed in EconLit comparing to WoS (138 to 255$)$ is probable less citations as well.

\subsection{Citations}

255 articles of Slovak professors appointed since 1993 have been 105-times cited. 1 paper was quoted 0.1 -times in average, well below the country average of 0.51 computed in Table 2. Only 21\% articles were at least once cited. There is one professor of economics with h-index of 3 , five with 2 , twenty two has 1 . Vast majority of new professors (74) has never published an article to which someone would refer.

For comparison - in the Czech Republic, there are 25 economic scientists with h-index higher than 1 comparing to Slovak 6 (Macháček, Kocunová, 2008). The best economist with Czech affiliation reaches $\mathrm{h}=9$ even without self-quotations.

The top performer among the new professors of economics in Slovakia is prof. Juraj Nemec, appointed in 2000. He has h-index 3 as the only one from the chosen pool. 7 of his articles were at least once referred to, and with 11 citations he keeps the second position in this parameter. Most citations (22) are attributable to articles from Sona Ferencikova, appointed in 2004. Unfortunately, she only has 2 articles quoted more than once.

Is there any positive development? Were this the case, the non-publishing professors would be attributable to the period of early 1990s, era of excessive growth of both number and size of economic schools, pulled by the growing demand for professionals in a forgotten field. Unfortunately, the latest professor with no relevant scientific result (i.e., no paper published) was appointed in 2008.

\section{Conclusions and Recommendations}

We have clearly shown that state of the economic research in Slovakia is not good. Slovak researchers have few publications, most of them in local papers with low impact. These results are hardly referred to. Research results of the whole Slovak economic science, measured in a standard way by publications and citations, or by more sophisticated Hirsch index, do not reach the level of even young individual researchers from the developed countries. Furthermore, the scientific results of Slovak professors of economics are even lower than the poor country average. We think that low attendance paid to research as a substantial and inevitable part of academic career is one of the clear roots of the general underperformance. We would strongly recommend to the policy makers to adopt and enforce strict rules and requirements, so that people with no scientific track record would not become professors. We consider professors to be the most influential group in the academia. In case they records are poor, the influence they have is not beneficial neither for their students, nor for the academic environment as such. It would for sure be advisable to scan the existing professors 
of economics for their research results, and consider keeping the privilege to bear the title to those who have at least some. In case this will not be adopted, the policymakers should only accept professors with some minimal proven scientific results to become guarantors of study programs on public universities. As the second possible step, only results published in English and abroad should be taken into account. Unless strict measures of this or similar kind are applied, there will be only small chances for radical improvement of the situation we have described in the article.

\section{References}

Artlová, M. (2010), "Problém měření a hodnocení individuální vědecké výkonnosti." Politická ekonomie, Vol. 58, No. 3, pp. 392-401.

Blaug, M.(1985), Economic Theory in Retrospect. Cambridge (UK): Cambridge University Press, 1985.

Boyes, W. J., Happel, S. K., Hogan, T. D. (1984), "Publish or Perish: Fact or Fiction?" Journal of Economic Education, Vol. 15, pp. 136-141.

Ciaian, P., Pokrivčák, J., Rajcaniová, M. (2005), "Stav ekonomickej vedy na Slovensku." Finance a úvěr (Czech Journal of Economics and Finance). Vol. 55, No. 11-12, pp. 546-562.

Della Seta, M., Cammarano R. R. (2006), "Google Scholar and Web of Science: Similarities and Differences in Citation Analysis of Scientific Publications," in 10. Conference of the European Association for Health Information and Libraries. Proceedings. September 11-16, 2006, Cluj-Napoca, 2006.

Fidrmuc, J. (1998), "Economic Education and Research Capacity Building in Slovakia." [mimeo]. Vienna: Vienna, Institute of Advanced Studies, September 1998.

Hirsch, J. E. (2005), "An Index to Quantify an Individual's Scientific Research Output." Proceedings of the National Academy of Sciences of the United States of America, 102(46): pp. 16569-16572.

Horváth, J. (2009), "Osobnosti v slovenskom ekonomickom výskume: krátky historický náčrt." ARRAnewsletter. March 2009, p. 7.

Macháček, M., Kolcúnová, E. (2008), "Hirschovo číslo a žebřǐček českých ekonomů." Politická ekonomie. Volume 56, No. 2, pp. 229-241.

Pišút, J., Pišútová, N. (2007), "Kritériá pre habilitácie docentov a inaugurácie profesorov a ich vplyv na kvalitu a rozsah publikačnej činnosti uchádzačov." ARRAnewsletter. October 2007, p. 4.

Sinuany-Stern, Z., Mehrez, A., Barboy, A. (1994), "Academic Departments Efficiency via DEA." Computers \& Operations Research, Vol. 21: pp. 543-556.

Šípoš, G. (2009), "Slovak Press Watch: Monitoring novinárskej práce." [online]. Available at http:// spw.blog.sme.sk.

Tol, R. S. J. (2009), "The h-Index and Its Alternatives: An Application to the 100 Most Prolific Economists." Scientometrics, Vol. 80, No. 2, pp. 317-324.

Van Dalen, H. P. (1997), "Measuring Giants and Dwarfs: Assessing the Quality of Economists." Scientometrics, Vol. 38, No. 2, pp. 231-252. 